\title{
Cesarean sections in Brazil's teaching hospitals: an analysis using Robson Classification
}

\author{
Yluska Myrna Meneses Brandão e Mendes ${ }^{1}$ and Daphne Rattner ${ }^{1}$
}

Suggested citation Mendes YMMB, Rattner D. Cesarean sections in Brazil's teaching hospitals: an analysis using Robson Classification. Rev Panam Salud Publica. 2021;45:e16. https://doi.org/10.26633/RPSP.2021.16

ABSTRACT

Objective. To determine the distribution of cesarean sections performed in teaching hospitals participating in the Project for Improvement and Innovation in the Care and Teaching of Obstetrics and Neonatology (Apice ON) using the Robson Classification.

Methods. Cross-sectional descriptive study on cesarean sections performed at Apice ON hospitals according to the Robson Classification, using secondary data from the 2017 Live Births Information System on the year prior to project implementation, hence a baseline study. Hospitals are described according to their geographic distribution and cesarean section rates, using absolute and relative frequencies.

Results. The proportions of newborns by Robson groups were similar to those proposed by the World Health Organization, except for Group 5 (with previous cesarean section) and Group 10 (preterm), with regional differences. The teaching hospitals' average cesarean section rates ranged from $24.8 \%$ to $75.1 \%$, exceeding by far the recommended values, even in Robson groups considered low risk for cesarean section (Groups 1 to 4 ). Conclusions. Brazilian teaching hospitals displayed cesarean section rates higher than those recommended by the World Health Organization for all groups; a worrisome fact, as by teaching they induce attitudes in future professional practices. These results highlight the importance of a reliable information system. Monitoring and evaluation of cesarean sections using the Robson Classification can be an important tool to guide management and propose actions to reduce rates. Countries with high cesarean section rates might explore this hypothesis in their teaching hospitals in order to define policies for the reduction of their rates.

Keywords Cesarean section; information systems; hospitals, teaching; Brazil.

There is a growing concern worldwide about the increase in the rates of cesarean section (CS), considering a recommendation from the World Health Organization (WHO) that population CS rates should not exceed $15 \%$ of all births (1). This problem is more relevant for Latin America, as various countries displayed remarkably high CS rates by 2018: Dominican Republic (58\%); Brazil (56\%); Venezuela (52\%); Chile (50\%); and Colombia, Ecuador, and Paraguay (46\% each) (2).

When well indicated, CS are generally associated with benefits for mothers and babies $(3,4)$. However, elective CS might affect maternal and neonatal morbidity and mortality, in the short and the long term.
Brazil has one of the highest CS rates in the world (2) and hence a significant proportion of potentially unnecessary procedures (5). The rate peaked at 57\% in 2014, decreased to $55.5 \%$ in 2015 and remained at 55.7\% in 2017 (6), despite government efforts to reduce it. CS rates are higher in the southern, southeastern, and midwestern states; lately, the northern and northeastern states' rates have shown accelerated growth, reducing regional differences.

Some socioeconomic factors, such as women's education, age, and having health insurance, are associated with higher rates, together with obstetric and fetal conditions (7). Another important factor is the interventionist model of care.

\footnotetext{
1 University of Brasilia. Brasilia, Brazil. $\square$ Yluska Myrna Meneses Brandão e Mendes, yluskamyrna@yahoo.com.br
} 
In 2011, the Brazilian Ministry of Health launched the program Stork Network (in Portuguese, Rede Cegonha), designed to change the model of care and improve the quality of perinatal care by providing the necessary structure and proposing changes in the processes of care. Despite this program, CS rates continued to rise: in 2011, the national rate was $53.7 \%$ and by 2017 it had reached $55.7 \%$, as mentioned.

Acknowledging the importance of teaching hospitals $(\mathrm{TH})$ in reproducing inadequate models of care, the Ministry of Health, in a joint effort with the Ministry of Education, launched the Project for Improvement and Innovation in Care and Teaching of Obstetrics and Neonatology (Apice ON) in August 2017. It aims to qualify clinical training, care management in relation to pregnancy, childbirth, and miscarriage, as well as TH management. This project intends to change the current model of care into one founded on evidence-based practices, humanization, safety, and guarantee of rights (8), involving $97 \mathrm{TH}$ in all states. It emphasizes the important role of these hospitals in forming the attitudes and practices of future professionals, a strategic measure to enable future change of practices.

The diversity of scenarios requires advanced forms of monitoring and evaluation in order to allow both the government and society to identify unnecessary CS at different contextual levels. In 2001, Robson (9) proposed a classification based on the risks for the surgical procedure, which enables monitoring as well as identifying unnecessary occurrences, both at the population and the service levels, but in a standardized, reliable, and consistent way, aimed toward action. A 2011 systematic review recommended its adoption (10), which was supported by WHO in 2015 (1).

The Robson Classification allows for the analysis of service practices and the construction of goals and interventions to ensure safe obstetric care, with acceptable CS rates (9-11), and was even used in a WHO study focusing on maternal and perinatal health in Latin America (12). This standardized classification used obstetric characteristics to build 10 epidemiological risk groups for the surgical procedure, allowing a rational analysis of CS rates, as well as comparing, evaluating differences, and proposing actions. One of its greatest pluses is the simplicity of its implementation in obstetric care services (13). For this reason, it was appointed by WHO as the most suitable system for local, national, and international use (1).

Since 2011, the Brazilian Live Births Information System (Sinasc) incorporated the variables necessary to stratify births into the 10 Robson Classification groups (14). In 2017, only 5\% of births could not be classified (6).

This study aimed to determine the distribution of CS performed in $\mathrm{TH}$ participating in the Apice ON project, according to the Robson Classification, using the live birth data available in Sinasc, exploring its potential for analysis and, in parallel, through this example, to highlight the importance of a reliable national information system that allows the use of the Robson Classification for different levels of analysis.

\section{MATERIALS AND METHODS}

This is a descriptive cross-sectional study applying the Robson Classification to CS performed at Apice ON project hospitals, using official data from the Sinasc database, utilizing the 2017 data for all TH included in the project $(n=97)$ prior to its implementation, hence as a baseline study. To be included in the Apice ON project, $\mathrm{TH}$ had to be certified by the Federal Government and have assisted over 1000 deliveries in 2015, according to the Hospital Information System (SIH/SUS) (8).

The Tabwin application was used for data extraction and tabulation, and Microsoft Excel version 2016 was used for the analysis. Results are presented in tables, using absolute and relative frequencies, analyzing data by state and region. For administrative purposes, due to its large number of hospitals, São Paulo state was classified by the project as Southeast II, and the other southeastern states remained as Southeast I, according to information available at the project website (https://portaldeboaspraticas.iff.fiocruz.br/apice/o-projeto/ hospitais-que-integram-o-projeto-apice-on/).

The variables included were 1) Characteristics of pregnancy: type of delivery (vaginal; CS); and 2) Robson group ranking.

\section{Robson group ranking}

The Robson Classification is based on the following obstetric parameters: parity; previous CS; gestational age; labor induction; whether the CS occurred before labor; fetal presentation; and number of fetuses (9). Group 1: Nulliparous, single cephalic, $\geq 37$ weeks, in spontaneous labor; Group 2: Nulliparous, single cephalic, $\geq 37$ weeks, induced or CS before labor; Group 3: Multiparous (excluding previous CS), single cephalic, $\geq 37$ weeks, in spontaneous labor; Group 4: Multiparous (excluding previous CS), single cephalic, $\geq 37$ weeks, induced or CS before labor; Group 5: Previous CS, single cephalic, $\geq 37$ weeks; Group 6 : All nulliparous breeches; Group 7: All multiparous breeches (including previous CS); Group 8: All multiple pregnancies (including previous CS); Group 9: All abnormal lies (including previous CS); Group 10: All single cephalic, <37 weeks (including previous $\mathrm{CS}$ ).

As this research used secondary data in the public domain, ethical approval was not required, according to Resolution No. 510/2016 of the National Health Council.

\section{RESULTS}

Table 1 shows that $28.7 \%$ of all Brazilian hospitals are in the Southeast and the region has $38 \%$ of the $97 \mathrm{TH}$. Given this concentration of hospitals, São Paulo state was classified as Southeast II, with 21 (21.6\%) hospitals. The second most populous region is the Northeast: $32.3 \%$ of all maternity hospitals are located there, while it has only $17.5 \%$ of the $\mathrm{TH}$, showing the inequal distribution. TH CS rates were high in all regions, especially the Midwest (53.1\%) and Northeast (53.3\%), and in particular in the states of Goiás (56.6\%) and Piauí (62.4\%). Lower averages were found in Southeast I (42.1\%) and South (45.2\%). The overall range was $24.8 \%$ to $75.1 \%$. TH displayed lower than regional CS rates, except in the Northeast. Only five (5.2\%) TH had CS rates under 30\% (data not shown) and rates were not related to number of births.

Table 2 shows that $59.5 \%$ of births were classified in Robson Groups 1 to 4 , with lower risk for surgical procedure, while $19.2 \%$ were in Group 5; hence, $78.7 \%$ of all births were in Groups 1 to 5 . There were differences between the North region and the others, with higher proportions in Groups $1(21.0 \%)$ and 3 $(25.9 \%)$ and smaller proportions in Groups $2(6.7 \%), 4(5.7 \%)$, 
TABLE 1. Distribution of hospitals and Apice ON project hospitals, comparing average cesarean section rates in Brazil's hospitals and Apice ON project hospitals; Brazil, regions, and states, 2017

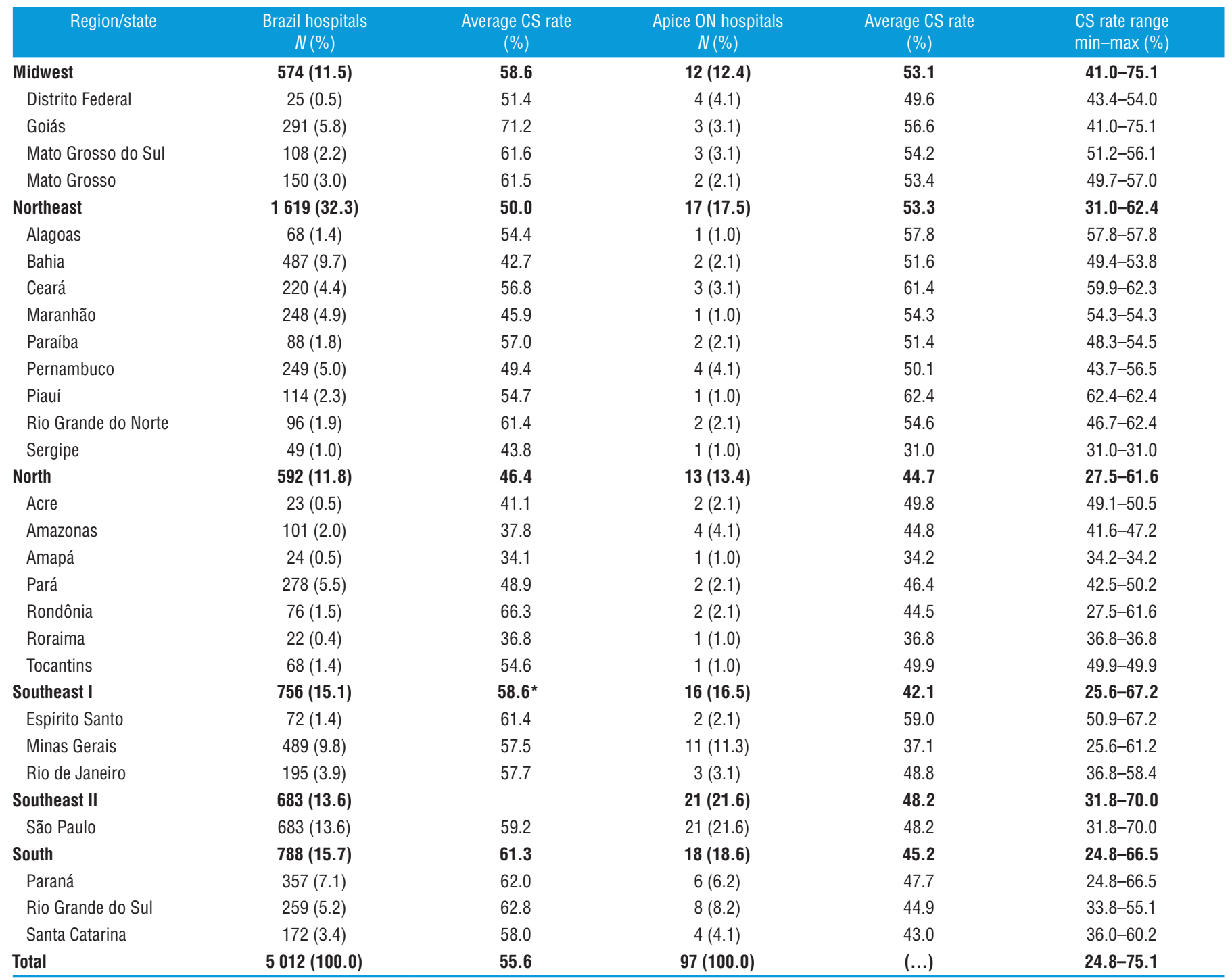

Source: Table prepared by authors based on research results. Data from MS/SVS/DANTPS/CGIAE/Sinasc. Notes: CS, cesarian section.

*This rate is for the Southeast, both Southeast I and II.

and $8(2.7 \%)$. On the other hand, Southeast II presented the lowest proportion in Group $1(13.6 \%)$ and the highest in Groups 2 $(14.7 \%)$ and $4(12.2 \%)$. The Midwest $(21.6 \%)$ and São Paulo $(21.5 \%)$ regions presented the highest proportions in Group 5, previous CS. The pelvic and abnormal presentations, Groups 6,7 , and 9 , corresponded to only $4.5 \%$ of births, being higher in the North (6.5\%). Group 8, multiple pregnancies, accounted for $3.5 \%$, being higher in the Northeast $(4.3 \%)$ and Midwest $(4.2 \%)$. Finally, Group 10, preterm births, represented $13.3 \%$, with higher proportions in the Northeast (16.9\%) and Midwest (14.1\%). The proportion of unclassified births (2.6\%) was higher in the Midwest and North (both with 5.5\%). Comparing with the proportions suggested by WHO (15), smaller proportions were observed for Groups 1 and 2 of nulliparae; on the other hand, the proportions were higher than the parameters suggested for Groups 5, 8, and 10.
Table 3 presents the CS rates for TH, comparing them with the WHO references (15). CS rates in all Robson groups were consistently higher than the references. The overall rate was $44.7 \%$, higher in hospitals of the Northeast (51.3\%) and Midwest $(49.5 \%)$. Adopting WHO values as references, for Group 1, the regions presented two to four times higher proportions; for Group 2, they far exceeded the reference range of $20 \%$ to $35 \%$, reaching $63.8 \%$ in the Midwest; for Group 3, they were from almost three (South) to eight times (Northeast) the upper limit; for Group 4, they ranged from 1.5 (Southeast I) to three times (Midwest) higher. In all regions there were higher proportions than those suggested by WHO for Group 5. For Groups 6, 7, and 9 (breech and other anomalous presentations) high rates and even $100 \%$ are acceptable due to the risks associated with normal births in these circumstances. WHO suggested a reference rate of $60 \%$ for Group 8 (all multiple pregnancies); this rate 
TABLE 2. Distribution of the proportions of live births by Robson Classification group in Apice ON project hospitals, and adopting WHO as reference; Brazil and regions, 2017

\begin{tabular}{|c|c|c|c|c|c|c|c|c|c|}
\hline Robson group & $\begin{array}{c}\text { Midwest } \\
\%(M)\end{array}$ & $\begin{array}{c}\text { Northeast } \\
\%(M)\end{array}$ & $\begin{array}{l}\text { North } \\
\%(M)\end{array}$ & $\begin{array}{c}\text { Southeast I } \\
\%(M)\end{array}$ & $\begin{array}{l}\text { Southeast II } \\
\%(M)\end{array}$ & $\begin{array}{l}\text { South } \\
\%(M)\end{array}$ & $\begin{array}{l}\text { Brazil } \\
\%(M)\end{array}$ & & $\begin{array}{c}\text { WHO* } \\
\%\end{array}$ \\
\hline G1 & $18.3(5069)$ & $16.4(11$ 196) & $21.0(14769)$ & $18.5(10435)$ & 13.6 (7 389) & 15.7 (8 033) & 17.3 (56 891) & \multirow{2}{*}{\}} & \multirow{2}{*}{$35-42$} \\
\hline G2 & $9.3(2571)$ & $12.6(8578)$ & $6.7(4728)$ & 13.7 (7 732) & $14.7(8003)$ & $14.4(7384)$ & 11.9 (38 996) & & \\
\hline G4 & $7.4(2044)$ & $11.2(7632)$ & $5.7(4012)$ & $11.4(6420)$ & $12.2(6$ 604) & $10.3(5295)$ & $9.8(32007)$ & \} & Around 30 \\
\hline G5 & $21.6(6001)$ & $18.1(12355)$ & $17.7(12420)$ & 18.1 (10 209) & $21.5(11688)$ & 20.1 (10 299) & $19.2(62972)$ & \multirow{3}{*}{\}} & Under 10 \\
\hline G6 & $1.5(409)$ & $1.8(1223)$ & $2.0(1417)$ & $1.2(699)$ & $1.3(727)$ & $1.8(919)$ & $1.6(5394)$ & & $3-4$ \\
\hline G8 & $4.2(1172)$ & 4.3 (2 915) & $2.7(1896)$ & $3.1(1757)$ & 3.8 (2 071) & $3.4(1764)$ & $3.5(11575)$ & & $1.5-2$ \\
\hline G9 & $0.3(74)$ & $0.3(195)$ & $0.1(97)$ & $0.2(98)$ & $0.2(134)$ & $0.4(207)$ & $0.2(805)$ & & $(\ldots)$ \\
\hline G10 & $14.1(3917)$ & $16.9(11551)$ & 13.6 (9 582) & 10.7 (6 038) & 11.4 (6 202) & $12.2(6260)$ & $13.3(43550)$ & & Under 5 \\
\hline Unclassified & $5.5(1630)$ & $2.4(1711)$ & $5.5(4063)$ & $0.9(490)$ & $0.2(91)$ & $1.2(641)$ & 2.6 (8 641) & & $(\ldots)$ \\
\hline Total & $100.0(29386)$ & $100.0(70011)$ & 100.0 (74 239) & 100.0 (56 999) & $100.0(54416)$ & $100.0(51808)$ & $100.0(336874)$ & & $(\ldots)$ \\
\hline
\end{tabular}

Source: Table prepared by authors based on research results. Data from: MS/SVS/DANTPS/CGIAE/Sinasc; and World Health Organization. Robson Classification: implementation manual. Geneva: WHO; 2017. Note: * Some of the values suggested by WHO are the sum of two groups. There are no reference values for Group 9.

TABLE 3. Distribution of cesarean section rates by Robson Classification group in Apice ON project hospitals, and adopting WHO as reference; Brazil and regions, 2017

\begin{tabular}{|c|c|c|c|c|c|c|c|c|}
\hline Robson group & $\begin{array}{l}\text { Midwest } \\
\%\end{array}$ & $\begin{array}{c}\text { Northeast } \\
\%\end{array}$ & $\begin{array}{l}\text { North } \\
\%\end{array}$ & $\begin{array}{c}\text { Southeast I } \\
\%\end{array}$ & $\begin{array}{c}\text { Southeast II } \\
\%\end{array}$ & $\begin{array}{l}\text { South } \\
\%\end{array}$ & $\begin{array}{c}\text { Brazil } \\
\%\end{array}$ & $\begin{array}{c}\text { WHO } \\
\%\end{array}$ \\
\hline G2 & 63.8 & 47.3 & 56.0 & 40.5 & 52.1 & 51.1 & 49.8 & $20-35$ \\
\hline G4 & 46.5 & 30.9 & 38.0 & 23.6 & 32.8 & 32.8 & 32.0 & Up to 15 \\
\hline G5 & 79.2 & 83.6 & 71.5 & 77.5 & 74.2 & 72.4 & 76.2 & $50-60$ \\
\hline G6* & 89.7 & 87.5 & 95.1 & 81.4 & 93.3 & 91.8 & 90.4 & $(\ldots)$ \\
\hline G8 & 85.2 & 79.2 & 81.1 & 75.5 & 82.8 & 78.8 & 80.1 & Around 60 \\
\hline G9* & 93.2 & 95.9 & 95.9 & 94.9 & 95.5 & 98.1 & 96.0 & $(\ldots)$ \\
\hline G10 & 47.1 & 50.7 & 41.3 & 42.2 & 48.3 & 47.6 & 46.3 & Around 30 \\
\hline Total & 49.5 & 51.3 & 43.0 & 37.8 & 44.8 & 42.9 & 44.7 & $(\ldots)$ \\
\hline
\end{tabular}
Source: Table prepared by authors based on research results. Data from: MS/SVS/DANTPS/CGIAE/Sinasc; and World Health Organization. Robson Classification: implementation manual. Geneva: WHO; 2017.
Note: * There are no reference values for Groups 6, 7, and 9 .

ranged from $85.2 \%$ in the Midwest to $75.5 \%$ in Southeast I. For Group 10 (all preterm infants), with about 30\% suggested, all regions had rates at least 1.3 times higher.

\section{DISCUSSION}

This article innovates by proposing to study obstetric practices in $\mathrm{TH}$ as potential determinants of high national CS rates and shows the potential of having routine data collection on variables related to mode of birth that allows for an assessment of different indicators. In the Brazilian birth certificate registry, Sinasc, it is possible to use the Robson Classification to assess the adequacy of the indications of CS, as shown in this study. Implemented in 2011, by 2017 only 5\% of birth certificates had missing information needed to allow classification (16). It is curious that in $\mathrm{TH}$, which should be a gold standard in terms of data quality, there were still $2.6 \%$ of births that could not be classified at the project onset (see Table 2). These indicators are available for different units of analysis: country, regions, states, towns, and individual hospitals. The Robson Classification is available for preliminary data in real time (17) so any hospital, municipality, or state can keep track of its evolution, as long as the birth certificate data are entered. A systematic review acknowledged how useful the Robson Classification is for audit and feedback (18); one of the TH included in this study even proposed to revise its protocols regarding induction in nulliparous women, as well as implementing vaginal birth after CS (19).

The overall range of the CS rate was $24.8 \%-75.1 \%$, exceeding by far the WHO acceptable standards. This analysis showed that the proportion of women in Group 5, with previous CS, was twice the WHO parameter $(19.2 \%$ vs. $<10 \%)$, evidencing the generalization of the surgical procedure, also for primipara, in Brazil. Proportions higher than the parameter in Groups 8 (twins) and 10 (preterm) may be associated with the fact that these are reference hospitals. However, high CS rates in Group $1(29.9 \%$ in $\mathrm{TH}$ vs. $<10 \%$ recommended) and even more so in Group 3 (13.4\% in TH vs. $<3 \%$ recommended), which are of 
very low risk for the procedure, suggest that $\mathrm{TH}$ do not follow obstetric and fetal indications.

The function of TH is to provide quality care and be a reference for future professionals (a gold standard), in addition to their responsibility as a practice field for undergraduate education and medical residency (20). This baseline assessment showed widespread excess of surgical births in $\mathrm{TH}$ of all regions of the country, suggesting inadequacy of their care model. Hotimsky and Schraiber (21), in an ethnographic study on how obstetrics is taught in a medical school in São Paulo, Brazil, reported a teacher mentioning in class that CS is a "modern, painless, safe, and efficient" way of giving birth. Probably, the promulgation of such attitudes during undergraduate studies and residencies reverberates in the care provided by today's obstetricians.

Moraes et al. (22) pointed to the responsibility of teaching in the generalization of cesarean births, presenting reports of teachers, students, and residents favorable to the procedure in view of its ease and speed, in addition to saving time, even while recognizing the importance of vaginal delivery. They also reported that the precise indications for CS were always taught, but that professionals found in the market a system that did not offer them the conditions to perform vaginal deliveries, thus preferring CS. This is contradicted by a study (23) which found that as early as 1993, the average CS rate of TH in São Paulo state was $39.1 \%$, ranging from $26.6 \%$ to $75.5 \%$ with an increasing trend, reinforced by the fact that in this state, the 2017 average $\mathrm{TH}$ rate was $44.8 \%$, ranging from $31.8 \%$ to $70.0 \%$ (data not shown). This suggests that when the Apice ON project began, few TH were fulfilling the role of teaching good practices, and they were not inducing change in the model of care.

The ideal CS rate was proposed to be around $7 \%$ (24), or between $10 \%$ and $18 \%$ (25). Since 1985 , WHO recommends a rate from $10 \%$ to $15 \%$ (1). Robson's article (2001) innovates by proposing to verify rates' appropriateness according to epidemiological risk criteria for surgical procedures by requiring a stated rationale for their performance, and by stating that reduction initiatives must be accepted by women and implemented safely (9).

For Groups 1 to 4, at low risk for this procedure, CS rate excesses were clear. Considering the national data for $\mathrm{TH}$, they were about three times higher than $\mathrm{WHO}$ recommendations for Group 1, 1.5 times higher for Group 2, more than four times higher for Group 3, and more than two times higher for Group 4 . These would be the groups of choice for designing CS-reduction actions. In Group 5, the rate was $15 \%$ to $25 \%$ higher than recommended, at $76.2 \%$ (suggested $50 \%-60 \%$ ). As mentioned, TH should be exemplary; these high rates reveal missed opportunities to teach vaginal birth after CS, possibly because of a preference to train surgical techniques.

The current dominant model of obstetric and neonatal care in the country-medical-centered and characterized by excessive interventions-should switch toward one that considers delivery and birth a physiological phenomenon, using appropriate technology and interventions, enabling appropriate ambience in birth centers for vaginal delivery, involving obstetric nurses in the monitoring and care for labor, delivery and birth, and respecting women's choices and rights (7) — striving for childbirth be a positive experience, as recommended by WHO since 2018 (26). Birth is culturally marked and shaped; hence, the transition between these models is very dependent on the local culture. In some countries, such as Japan, the Netherlands, and New Zealand, the latter model is prevalent, while in others, such as Greece, the United States of America, and some Latin American countries, Brazil included, the interventionist model prevails (27).

Brazilian public policy has been guided by a collective effort to make this change happen, aiming to: implement a collaborative model of care, which offers the sharing of responsibilities among doctors, obstetric nurses, midwives, and other professionals; harmonization of the work process; and, among the necessary interventions, implementing respect for the physiology of the birth process and the qualification of childbirth care (21).

This baseline study innovates by proposing that interventionist approaches in obstetrics might be derived from the way obstetrics is taught. A previous article on the same TH described how an important proportion of them do not follow the Brazilian Ministry of Health guidelines, some of which even stem from the 1980s, such as rooming-in, or from the 1990s, such as the international Baby-Friendly Hospital Initiative (28). This paper showed that these TH do not follow obstetric indications for surgical procedures, adding to the question on how obstetrics is being taught and what kind of professionals will come out from this educational process. It also reinforces the adequacy and opportunity of the Apice ON project as a means to change the teaching curricula, practices, and interventionist culture.

The limitations of this study derive from: use of a secondary database, with probable heterogeneity in the quality of birth certificate completion; lack of validation of conceptual definitions for variables such as "labor induction," which might have been identified with the use of oxytocin, while its use is also possible in the active management of care; and the worldwide lack of studies on TH on a national level, which would allow amplification of the discussion about the problem herein addressed. A survey of the existing literature identified studies only of individual hospitals.

Before Robson's proposal for CS classification by epidemiological risk groups, evaluations were made based solely on CS rate. His classification allows identification of lower and higher risk groups for CS, besides monitoring interventions to reduce rates in selected groups, and it is recommended by WHO. Betrán et al. concluded that interventions to reduce overuse of CS must be multicomponent and locally tailored, addressing women's and health professionals' concerns, as well as health system and financial factors (29). Silva et al. (19) listed some successful strategies used by other authors to reduce CS rates: training professionals on evidence-based practices; implementation of standardized protocols for the main CS indications; audit and feedback; designation of a leader to coordinate these efforts; structural and organizational changes; and monitoring obstetric outcomes to assess quality of care.

All these possibilities for action depend on reliable data for decision-making. Other countries with similar problems, by adopting the Robson Classification in their routine data collection, might be able to identify where the excesses occur and on which groups to focus, and to design customized strategies to reduce their excess CS. As mentioned, the Brazilian panel allows monitoring of the data at the level of establishments, municipalities, states, and others, thus becoming an important tool for management. 
Brazilian TH display high CS rates even in groups at low risk for surgical procedures. This study's results strongly suggest that the excess of surgical interventions in births may be determined by what was learned and practiced during the professional training in $\mathrm{TH}$. Countries with high CS rates might explore this hypothesis in their $\mathrm{TH}$ in order to define policies for the reduction of their high rates.

Author contributions. YMMBM and DR conceived the original idea. YMMBM collected the data. YMMBM and DR analyzed the data, interpreted the results, and wrote the paper. Both authors reviewed and approved the final version.
Acknowledgments. The authors wish to thank Jorge Barreto for his critical appraisal of the manuscript, suggestions on the final version, and help with restructuring the tables; and Laura Uplinger for her careful and meticulous review.

\section{Conflicts of interest. None declared.}

Disclaimer. Authors hold sole responsibility for the views expressed in the manuscript, which may not necessarily reflect the opinion or policy of the RPSP/PAJPH and/or the Pan American Health Organization.

\section{REFERENCES}

1. World Health Organization. WHO Statement on caesarean section rates. Reprod Health Matters. 2015 May;23(45):149-50. doi: 10.1016/j.rhm.2015.07.007. Epub 2015 Jul 27.

2. UNICEF. The State of the World's Children 2019. Children, Food and Nutrition: Growing well in a changing world [Internet]. New York: UNICEF; 2019. Accessed 2020 Aug 10. Available from: https: / / www.unicef.org/sites / default/files / 2019-12/SOWC2019.pdf

3. Sevelsted A, Stokholm J, Bønnelykke K, Bisgaard H. Cesarean section and chronic immune disorders. Pediatrics. 2015;135(1):e92-e98. doi:10.1542/peds.2014-0596

4. Mylonas I, Friese K. Indications for and Risks of Elective Cesarean Section. Dtsch Arztebl Int. 2015;112(29-30):489-95. doi: 10.3238/ arztebl.2015.0489

5. Leal MC, Pereira AP, Domingues RM, Filha MM, Dias MA, Nakamura-Pereira $\mathrm{M}$, et al. Obstetric interventions during labor and childbirth in Brazilian low-risk women. Cad Saude Publica. 2014;30(Suppl 1):S1-S16. doi: 10.1590/0102-311x00151513

6. Brasil. Ministério da Saúde [Internet]. Painel de Monitoramento de Nascidos Vivos Brasília: Coordenação Geral de Informações e Análises Epidemiológicas/SVS/MS. Accessed 2019 May 13. Available from: http://svs.aids.gov.br/dantps/centrais-de-conteudos/ paineis-de-monitoramento/natalidade/nascidos-vivos/.

7. Rattner D, Moura EC. Births in Brazil: association between type of delivery and temporal and socio-demographic variables. Rev Bras Saude Mater Infant. 2016;16(1):39-47. doi: 10.1590/1806-93042016000100005

8. Brasil. Portal da Saúde [Internet]. Ministério da Saúde lança Projeto Apice ON - Aprimoramento e Inovação no Cuidado e Ensino em Obstetrícia e Neonatologia. Accessed 2019 Dec 10. Available from: https://portaldeboaspraticas.iff.fiocruz.br/apice/o-projeto/.

9. Robson MS. Can we reduce the caesarean section rate? Best Pract Res Clin Obstet Gynaecol. 2001;15(1):179-94. doi: 10.1053/ beog. 2000.0156

10. Torloni MR, Betran AP, Souza JP, Widmer M, Allen T, Gulmezoglu M, Merialdi M. Classifications for cesarean section: a systematic review. PLoS One. 2011;6(1):e14566. doi: 10.1371/journal.pone.0014566

11. Vogel JP, Betrán AP, Gülmezoglu AM. Use of the Robson classification has improved understanding of caesarean section rates in France. BJOG. 2015;122(5):700. doi:10.1111/1471-0528.13266

12. Betrán AP, Gulmezoglu AM, Robson M, Merialdi M, Souza JP, Wojdyla D, et al. WHO global survey on maternal and perinatal health in Latin America: classifying caesarean sections. Reprod Health. 2009;6:18. doi: 10.1186/1742-4755-6-18

13. Ferreira EC, Pacagnella RC, Costa ML, Cecatti JG. The Robson tengroup classification system for appraising deliveries at a tertiary referral hospital in Brazil. Int J Gynaecol Obstet. 2015;129(3):236-9. doi: 10.1016/j.ijgo.2014.11.026

14. Brasil. Ministério da Saúde [Internet]. Saúde Brasil 2015/2016: uma análise da situação de saúde e da epidemia pelo vírus Zika e por outras doenças transmitidas pelo Aedes aegypti. Brasília: Ministério da Saúde; 2017:18-35. Accessed 2019 Sep 13. Available from: http:/ / svs.aids.gov.br/dantps/centrais-de-conteudos / pub licacoes/saude-brasil/saude-brasil-2015-2016-uma-analise-da-situ acao-de-saude-e-da-epidemia-pelo-virus-Zika-e-por-outras-doen cas-transmitidas-pelo-Aedes-aegypti.pdf

15. World Health Organization. Robson Classification: implementation manual [Internet]. Geneva: WHO; 2017. Accessed 2020 Sep 13. Available from: https://apps.who.int/iris/bitstream/handle/1066 5/259512/9789241513197-eng.pdf

16. Brasil. Ministério da Saúde [Internet]. Saúde Brasil 2017: uma análise da situação de saúde e os desafios para o alcance dos objetivos de desenvolvimento sustentável. Brasília: Ministério da Saúde; 2018. Accessed 2019 Feb 12. Available from: http://bvsms.saude.gov.br/ bvs/publicacoes/saude_brasil_2017_analise_situacao_saude_desa fios_objetivos_desenvolvimento_sustetantavel.pdf

17. Brasil. Ministério da Saúde [Internet]. Brasília: Ministério da Saúde; 2020. Painel de Monitoramento de Nascidos Vivos Brasília: Coordenação Geral de Informações e Análises Epidemiológicas/SVS/ MS. Accessed 2019 May 13. Available from: http://svs.aids.gov. $\mathrm{br} /$ dantps / centrais-de-conteudos/paineis-de-monitoramento/ natalidade/grupos-de-robson/.

18. Boatin AA, Cullinane F, Torloni MR, Betrán AP. Audit and feedback using the Robson Classification to reduce caesarean section rates: a systematic review. BJOG. 2018;125(1):36-42. doi: 10.1111/1471-0528.14774

19. Silva LF, Almeida CP, Batista DF, Neto CM. Estudo da incidência de cesáreas de acordo com a Classificação de Robson em uma maternidade pública. [Study of cesarean section incidence according to Robson Classification in a public maternity hospital]. Femina. 2020;48(2):114-21. Accessed 2020 Aug 12. Available from: https: / / docs.bvsalud.org/biblioref / 2020/03/1052454/ femina -2019-482-114-121.pdf

20. Ayanian JZ, Weissman JS. Teaching hospitals and quality of care: a review of the literature. Milbank Q. 2002;80(3):569-v. doi: 10.1111/1468-0009.00023

21. Hotimsky SN, Schraiber LB. Humanization in the context of obstetric training. Cien Saude Colet. 2005;10(3):639-49. doi: 10.1590/ S1413-81232005000300020

22. Moraes MS, Goldenberg P. Cesáreas: um perfil epidêmico [Cesarean sections: an epidemic profile]. Cad Saude Publica. 2001;17(3):50919. doi: $10.1590 /$ s0102-311×2001000300007

23. Rattner D. Sobre a hipótese de estabilização das taxas de cesárea do Estado de São Paulo, Brasil [On the hypothesis of cesarean birth rate stabilization in southeastern, Brazil]. Rev Saude Publica. 1996;30(1):19-33. doi: 10.1590/s0034-89101996000100004

24. Francome C, Savage W. Caesarean section in Britain and the United States $12 \%$ or $24 \%$ : is either the right rate? Soc Sci Med. 1993;37(10):1199-218. doi: 10.1016/0277-9536(93)90332-x

25. Pettiti DB. The ideal cesarean section rate. In: Parer JT, editor. Antepartum and intrapartum management. Philadelphia: Lea \& Febiger 1989. c. 16.

26. World Health Organization. WHO recommendations: intrapartum care for a positive childbirth experience [Internet]. Geneva: WHO; 
2018. Accessed 2020 Sep 13. Available from: https://apps.who.int/ iris/bitstream/handle/10665/260178/9789241550215-eng.pdf

27. Davis-Floyd R, Cheyney M. Birth in eight cultures. Long Grove, IL: Waveland Press; 2019.

28. Mendes YMMB, Rattner D. Structure and practices in hospitals of the Apice ON Project: a baseline study. Rev Saude Publica. 2020;54:23. https://doi.org/10.11606/s1518-8787.2020054001497

29. Betrán AP, Temmerman M, Kingdon C, Mohiddin A, Opiyo N, Torloni MR, et al. Interventions to reduce unnecessary caesarean sections in healthy women and babies. Lancet. 2018;392(10155):1358-68. doi: 10.1016/S0140-6736(18)31927-5

Manuscript submitted on 20 May 2020. Revised version accepted for publication on 16 September 2020

\section{Cesáreas en los hospitales universitarios de Brasil: análisis empleando la clasificación de Robson}

RESUMEN

Palabras clave
Objetivo. Utilizar la clasificación de Robson para determinar la distribución de las cesáreas realizadas en los hospitales universitarios que participan en el proyecto para la mejora y la innovación en la atención y la enseñanza de la obstetricia y la neonatología (Apice ON).

Métodos. Se empleó la clasificación de Robson para realizar un estudio descriptivo transversal sobre las cesáreas realizadas en los hospitales del proyecto Apice ON. Se utilizaron datos secundarios procedentes del Sistema de Información de Nacidos Vivos del 2017 correspondientes al año anterior a la ejecución del proyecto, a modo de estudio de referencia. Los hospitales se clasifican según su distribución geográfica y sus tasas de realización de cesáreas, usando frecuencias absolutas y relativas.

Resultados. Las proporciones de recién nacidos por grupos de Robson fueron similares a las propuestas por la Organización Mundial de la Salud, a excepción de los grupos 5 (con cesárea anterior) y 10 (prematuro), con diferencias regionales. Las tasas de cesárea promedio de los hospitales universitarios variaron entre el 24,8\% y el $75,1 \%$. Estos valores superan con creces los valores recomendados, incluso para grupos de Robson considerados de bajo riesgo de cesárea (grupos 1 a 4).

Conclusiones. Los hospitales universitarios de Brasil mostraron tasas de realización de cesáreas superiores a lo recomendado por la Organización Mundial de la Salud para todos los grupos. Este hecho es preocupante, ya que estos centros pueden incentivar ciertas actitudes en la práctica de los profesionales que forman. Estos resultados ponen de relieve la importancia de un sistema de información fiable. El seguimiento y la evaluación de la realización de cesáreas mediante la clasificación de Robson puede ser una herramienta útil para guiar la gestión y proponer medidas dirigidas a reducir las tasas. Esta hipótesis puede ser de interés para aquellos países con tasas elevadas de cesárea, cuyos hospitales universitarios podrían emplear este enfoque para definir políticas de reducción de sus tasas.

Cesárea; sistemas de información; hospitales de enseñanza; Brasil. 


\section{Cesáreas em hospitais de ensino no Brasil: análise de acordo com a Classificação de Robson}

RESUMO Objetivo. Determinar a distribuição dos partos cesárea realizados em hospitais de ensino integrantes do Projeto de Aprimoramento e Inovação no Cuidado e Ensino em Obstetrícia e Neonatologia (Apice ON) de acordo com a Classificação de Robson.

Métodos. Estudo descritivo transversal de partos cesárea realizados em hospitais integrantes do Projeto Apice ON de acordo com a Classificação de Robson com base em dados secundários do Sistema de Informação sobre Nascidos Vivos (SINASC) de 2017 no ano anterior à implantação do projeto. Trata-se, portanto, de um estudo da linha de base. A análise foi realizada segundo a distribuição geográfica e as taxas de partos cesáreas dos hospitais, com o uso de frequências absolutas e relativas.

Resultados. Os percentuais de recém-nascidos pelos grupos da Classificação de Robson foram similares aos propostos pela Organização Mundial da Saúde (OMS), exceto para os grupos 5 (parto cesárea anterior) e 10 (parto prematuro), com variação regional. A taxa média de partos cesárea nos hospitais de ensino oscilou entre $24,8 \%$ e $75,1 \%$, um patamar que está bem acima dos níveis recomendados, inclusive nos grupos de baixo risco para cesárea (grupos 1 a 4).

Conclusões. Os hospitais de ensino no Brasil têm taxas de partos cesárea maiores que as recomendadas pela OMS para todos os grupos. É um fato preocupante porque o aprendizado é um indutor das práticas profissionais futuras. Os resultados deste estudo apontam para a importância de sistemas de informação confiáveis. O monitoramento e avaliação das cesáreas de acordo com a Classificação de Robson constituem um instrumento útil para orientar a conduta e propor ações para reduzir das taxas. Os países com altos índices de cesáreas deveriam considerar este modelo nos seus hospitais de ensino visando definir políticas para a redução das taxas.

Palavras-chave Cesárea; sistemas de informação; hospitais de ensino; Brasil. 